\title{
EL ÚLTIMO TEXTO EDUCATIVO DE SARMIENTO: SOBRE EL MÉTODO DE ESTUDIOS DE SAN ISIDRO DE MADRID
}

JOSé SANTOS PUERTO

A Don José Filgueira Valverde, in memoriam '

Tras la expulsión de la Compañía de Jesús en 1767, todas sus dependencias fueron temporalmente cerradas, a la espera del inventariado de sus rentas y de su acomodación a las nuevas funciones que los golillas de Carlos III les tenían reservadas. Después de nuchas tensiones e incertidumbres, las cátedras jesmitas de todas las universidades y estudios quedaron extinguidas por real cédula de 12 de agosto de 1768 , al tiempo que la mayor parte de los colegios eran destinados a actividades que poco tenían que ver con el fomento de la educación y de la cultura, de ese supuesto ídolo místico ilustrado de la culture utilitaire et dirigée que Jean Sarrailh creyó incompatible con la raison philosophique, desorientando en huena medida la investigación posterior .

El antiguo Colegio Imperial, el más importante y elitista de los centros que los jesuitas tenían en España, fue uno de los pocos que recobró su actividad

La dedicatoria tenía un especial significato tuando escribí una primera vessión de la jresentación del texto de Samiento, en el mes de septiembre de 1996. La excesiva "xtensión no favoreció su publicación, por lo que la introducxión que ahora se hace es sustancialmente diferente. Sin emlyargo, a pesar del año y medio que ha transcurrido, el lomenaje al académico de la historia, lerviente estudioso de fray Marlín Sarniento, tiene el mismo sentido. 
tducativa, con aires de modernización y nuevo nombre: los Reales Estudios de San Isidro de Madrid. De allí, de la renovación de cátedras y de la adscripción del profesorado mediante la convocatoria de oposiciones públicas anunciadas previamente, pero también de las luchas y conflictos organizativos, se habría originado, al decir de Antonio Viña ${ }^{2}$, el corps professionnel de la enseñanza superior española.

Aunque la historia del colegio de la Compañía en Madrid, más tarde Colcgio Inpustial y después Reales Estudios de San Isidro, yad ha sido escrita por José Simón Díaz", persisten, no obstante, abundantes zonas de sombra durante el tiempo que media entre lá expulsión y la inauguración oficial del nuevo centro en octubre de 1771. No es intrasccndente que ese tiempo se llene algúm día de luces, porque, como ya advirtió Aguilar Piñal al valorar la actuación de la comisión eneargada do administrar las rentas incautadas a los jesuitas, una de las principales causas del fracaso de la política cultural y educativa ilustrada se debió a *la inculerencia del equipo gobernante, envuelto en mil contradicciones, nacidas de intereses contrapuestos. Es decir, por la equivocada pretensión de lacer una reforma cultural sin dañar los privilcgios de clase, respetando los presupucstos econónicos y sociales de la sociedad cstamentaln".

Al liompo de decretarse la supresión de las cátedras jesuíticas y de restableserse provisionalmente la actividad docente de los Reales Fstudios, cra nombrado director interino Felipe Samaniego", quion a mediados de octulore de 1768 fue insiado por el Consejo de Castilla para que elaborara un plan de estuclios y de organización del cerntro. Finalisado a principios de 1769, el plan incluín retórica, poesía, lenguu castcllana, la1ín, gricgo y hcbreo, adcmás de historia literaria, derecho púhlico, matemáticas, historia natural y filosolía

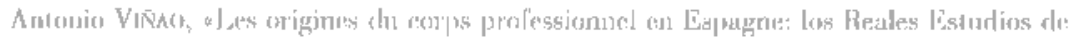

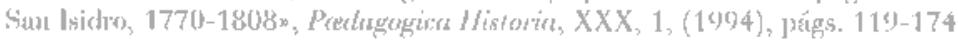

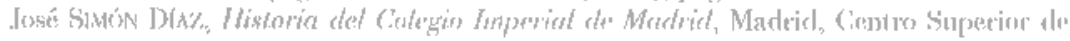

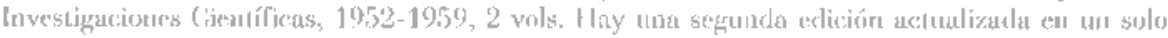

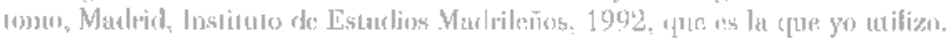

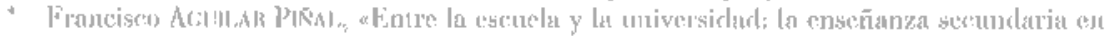

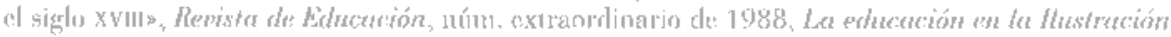

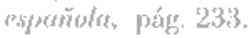

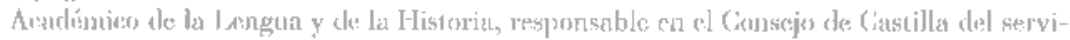

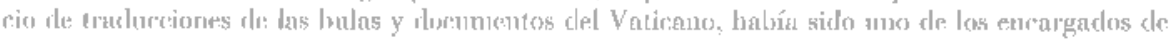

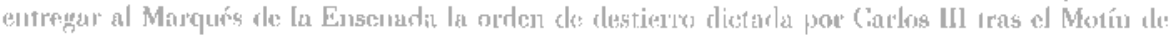
lisprutulaclus: 
modernat. Desaparecían los estudios escolásticos, al igual que el elaborado por Olavide para la universidad de Sevilla, lo que provocó airadas protestas anónimas ante el Consejo, que, sin embargo, no impidieron su aprobación el 19 de enero de 1770 , al tiempo que Carlos 1 II restablecía oficialmente los Reales Estudios. Las protestas decidieron, no obstante, la no continuidad de Samaniego al frente del centro, cuando dos meses después el Consejo elevó a Carlos III la propuesta para director definitivo.

Martín Sarmiento (Villafranca del Bierzo, 1695 - Madrid, 1772), el conocido benedictino defensor y discípulo (en muchos aspectos maestro) de Benito Jerónimo Feijoo, era gran amigo de Camponanes y de Samaniego ${ }^{7}$. Por esta razón, ya por decisión propia o ya instado por Campomanes, el director provisional de los Reales Estudios recabó la opinión del benedictino en relación con el plan de estudios. Su respuesta es el texto que aquí se presenta, Sobre método de Estudios de San Isidro, último de carácter estrictamente edıcativo que escribió el de San Martín de Madrid.

Desde mi punto de vista, ni Samaniego ni Campomanes pretendian que fray Martín aportase novedades al plan, puesto que ya entonces el berciano padecía alguna variante de la enfermedad de Parkinson, que apenas le permitía escribir, como él mismo manifiesta en su correspondencia y como muestran sus manuscritos. La consulta tenía más de cortesía y de obligación para con quien había orientado, desde el silencio y la sombra de su celda, las primeras reformas culturales de nuestro siglo XVIII: las propiciadas por Rávago primero, y las de Campomanes después. Por ello, si bien son interesantes sus apreciaciones en relación con el estudio de las lenguas clásicas, así como sus recomendaciones bibliográficas y de libros de texto, lo cierto es que nada sustancial aporta que no hubiera planteado ya en alguno de sus numerosos escritos pedagógicos anteriores.

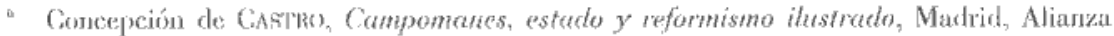

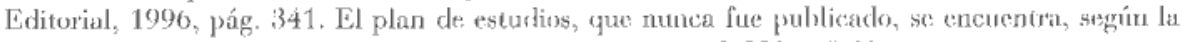
autora, en el Arehivo Histórico Nacional, Consejos, legajo 5.990, n." 61

A lit muerte de fray Martín, Samaniego fue, junto con Medinasidonia, Campontames y Ventura figueroa, 1010 de los primeros amiges del benediedino en suscribiese con 300 reales para pagar el husto de nárnol con el que Folipe de Custor perpetuatía su nemoria. Antonio Mesire nos recuerda yoe este Samaniego, tras la condema de Olavide, confesó volumtariantente ante la infuisición ser lector de Spimozza, Bayle, Voltaire, Diderot, Runsscau, y ouros autores prohibides, e indicó el nombre de alsunos políricos y hounlores relevantes de su tiempo (ente otros. Floridablunea, Campomanes, Aranda, Alenorlóvar) que también los habían leírln. Ver Autonio MESTRE SANCHis, Religión y cultura en el siglo xvils, cn Historia de la Iglesia en bspañu, tomo IV, Madrid, Bilsliveca de Autures Ciristianos, 1979, pág. 712. 
Ni la consulta que se hace a Sarmiento ni su respuesta pueden analizarse en el contexto del debate entre la philosophia modema lrente a la metafísica escolástica, que es lo que predoninó cuando los planes de Olavide y de Samaniego se conocieron. Analizado el escrito de Sarmiento desde esa óptica, corremos el riesgo de malinterpretar su pensamiento, como le ocurrió al copista cuando apostilló: "viene a reprobar en sustancia todo el nuevo método, teniendo por más seguro el que se siga el antiguo». Para entender el pensamiento cducativo y reformista de Cray Martín hay que volver cuarenta anos atrás, como él mismo nos dice al commenzar el escrito.

En efecto, fue cuarenta años antes cuando samiento escribió su primer rexto de reforma, enviado al entonces general de la orden benedictina, Francisco Berganza. Allí decía algo que continuó afirmando en todos sus escritos pedagógicos, y que nos permite entender mejor su pensamiento, y el porqué de la consulta de Samámiego:

«Para que en mestra rehigión se acalore la virtud, es preciso acalorar las lemas primero [...] No hablo de aquellas letras (digase asi) de pane tuevanrlo, que en la orden se usatr, $n$ g. de una pura teología metalísica o ma pura netafísica teológica; o de una oratoria pueril o de puerilidades pulpitablos; que rodo esto, ni adoma, ni cxormi, ní gusta, ni hace docto, ni menos abro camino para la virtud, pues su misma futilidad enfada a los mismos que las posections.

Exiraña manera de expresarse del cntonces doctor y macstro de teología. predicador mayor de San Martín, si no supiéramos que él fue uno de los primeros en dejar de lado los cartapacios de metafísica y los sermones de puerilidades pulpitables para dedicarse a otros cstudios. Por eso, para entender lo que fue, y lo que no tue, nuestra llustración, es necesario seguir los pasos de fray Martíu y recorrer con él todos sus raminos.

Podrenos verlo, junto a Feijoo, tomando el relevo de los novatores en su incansable batalla contra los negros tenebrarios que niegan el futuro de Espana, escudandose en la radición y en un glorioso pasado, que en realidar desconocen. Lo veremos estudiando matemáticas y filosofía morlerna, y sabremos entonces de su importante contribución a la introducción de Newton en

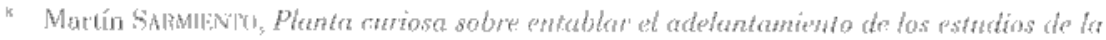

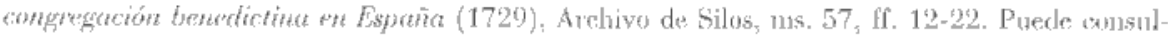
ialse ene la edición que hemos preparado pata la Revista de historia y sociología dre la educacion

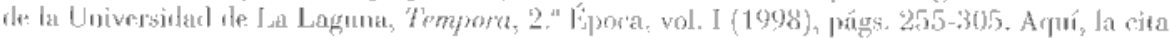
etl pág. 293 
España". Lo veremos descubrir los orígenes de la poesía castellana en los claustros de San Millán, realizando la primera edición de un texto de Berceo, las 777 cuartetas de la Vida de Santo Domingo de Silos". Lo vercmos escribir la primera historia de la poesía española y mostrar el vínculo de la lírica galaicoportuguesa con la castellana, en base a la hasta entonces desconocida CarlaProhemio del Marqués de Santillanu y a las Cantigas de Alfonso el Sabio. Lo veremos formular las leyes evolutivas del lauín ch el tránsiro hacia las lenguas vulgares y pergeñando lo que después conoceremos como lingüistica románica". Lo veremos estudiar historia natural, para ser mo de los primeros españoles en valorar la obra de Linneo. Y en fin, para no cansar, lo veremos adelantarse a sus contemporáneos para valorar la cultura popular, para poner en práctica nucvas concepciones de la investigación histórica, y para construir los ideales utópicos de muestra ilustración, esos ideales que, si hiciéramos caso de Franco Venturi y de José Antonio Matavall, numea habrían existido.

El texto que aquí se presenta tiene más válor testimonial que podagógico o lingǘstico. Quiero decir con allo que apenas aporta novedades sobre lo que ya había dicho en otros escritos, pero nos sirve para entender los últimos tramos del camino que hemos iniciarlo en 1729. Nos sirve para comprender que el benedictino tuvo una gran participación en el proceso de renovación cultural de la España de su tiempo, que no se agotó, aunque sí se silenció, con la llegada de Carlos IH. Así, sabiendo abora de su pequeña participación en el plan de estudios de San lsidro, junto con Samaniego y Camponanes, quizás no sorprenta saber que buena parte de los articulos de la Real Cédula de Instrucción y Fuero de Poblarion de Siema Morena están tomados casi al pie

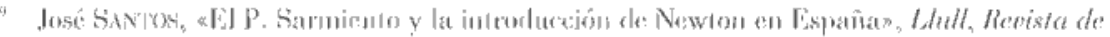

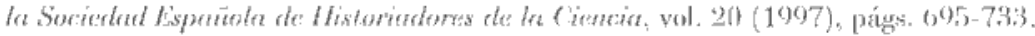

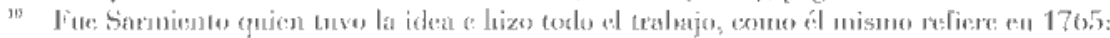

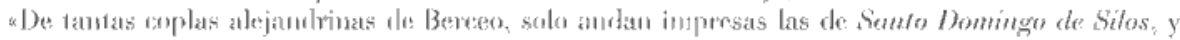

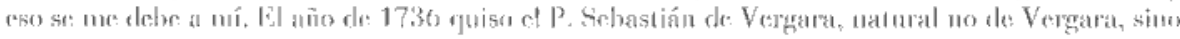

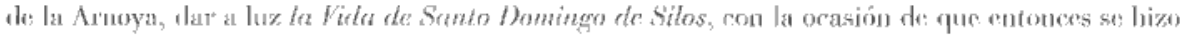
la Fiesia de la Translación. Disuadíle que formase un torno de las sermones que se lazbian predi-

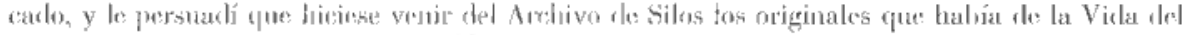

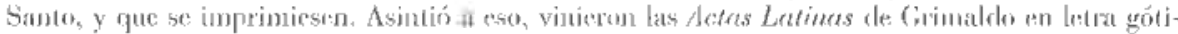

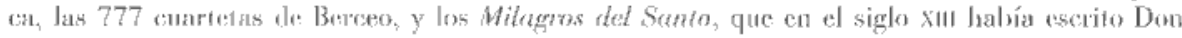
Pedro Marin. Vi esos lore precioses monumbentos y constatí gustoso en que, pasando por mis ojos

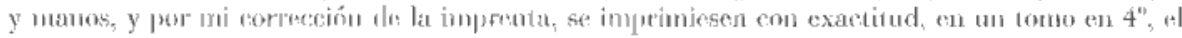

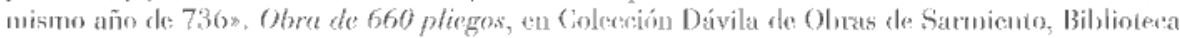
Nacional, tomo XV1, parígralo, 5430)

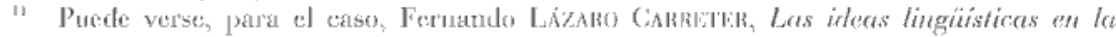

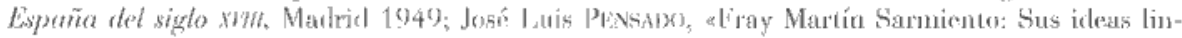




de la letra de su Obra de 660 pliegos ${ }^{12}$. Quizás sorprenda aún más saher que Sarmiento escribió en 1764 estos párrafos, que nos permiten entender por qué el manuscrito de La Sinapia se encontró en el Archivo de Campomanes, y nos fuerzan a dirigir la mirada hacia un tiempo y un lugar diferentes a los de Stelio Cro y François Lopez para dar con el rastro del autor, como hatemos en otra orasión.

«Al fin, hán de parar en la España Austral, que se imaginará unæk granste isla en el Pacifico, y en clonde corresponde los antípodas de Madrid, como ya dije en otra parte. El derrotero de esta navegación ha de seguir por las mismas regiones por donde se hizo el primer viaje. El derrotero de los Atlds de. Holuake podrá servir parı guiar la navegación de todus mares. Y, para girar y descubrir todas las islas, servirán los dos tomos atlánticos del lsolario del Padre Coroneli, gue describe las islas de todo el inundos [...].

"El fin de los viajcros es buscar, hallar, y poblar ma grande isla, que esté como antípoda de España, allá en el Mar Pacífico. En esa isla, que será la má́s sama, fértil, annena, rica y espaciosa de todo el inundo, han de lijar los viajeros su habitación para siempre, y allí futudarán un feliz imperio. Fisto será saliendo ya del Pueru de Finistere, casados todos los viajeros.

* Putesta la verídica novela en ese estado, y en esa isla antípoda de España, y que cn clla se imaginarán los Campos Elíscus, tendrá el autor un vastísino campo para imaginar un vestísino feliz intperio con cl ejercicio de una justísinna filosofía moral eristinna, y corregir la de la Ciudad det Sol, de la Utopúie de Tomás Moro y de la Atlántida de: Plarón. (Olas Rudbek colocó la Isla Atlántida en la Fscandinavia, y Kirchunajero dice que Platón uniro tracens cxtremos Africa versus Atsisum, atque Occidentem. Si hacia allí estaba la Isla Ailantis es cierto que hacia allí están los antípodas de España, u la España Austral. Dejandos puestesta femtasía que se me propusus para yue

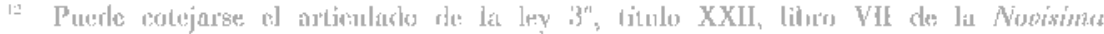

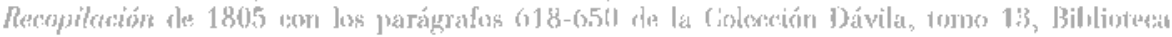

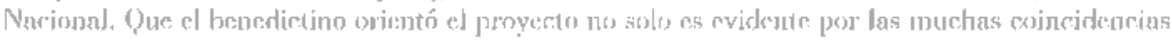

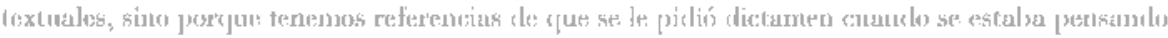

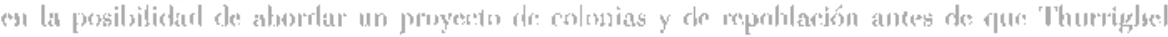

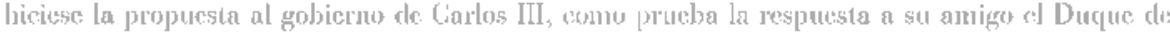

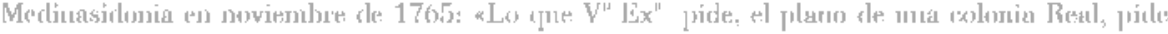

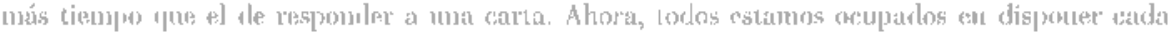

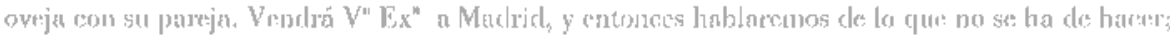

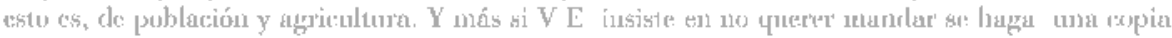

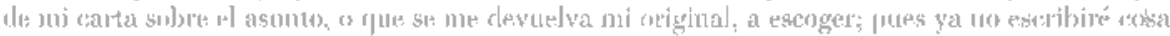



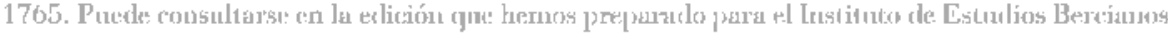

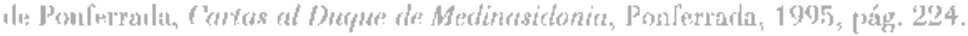


se escribiese una obra que contuviere todas las voces castellanas, no desisto de que se escriba esa obra, y sea la que se quisicre" ":

Párrafos que sirven para afirmar que si hoy desconocemos la gran influencia que Sarmiento ejerció en la renovación de las ciencias, de la cultura y de las letras de nuestro siglo XVII, no sólo se debe a su tenaz negativa para que su nombre apareciera en negro solbre blanco en los muchos proyectos en que participó, sino a los silencios y desprecios que los ilustrados plenos tuvieron para con uno de los escasos integrantes del autre côté de la ilustración española. De la ilustración aún por estudiar, de la ilustración utópica española, silenciada tras la llegada de Carlos IIl y amordazada a partir de 1767.

El sentimiento y la utopía fueron las armas que encumbraron a la Raison y a las Lumieres en Francia, porque las desavenencias en las filas de los cacoutcs, las desavenencias entre Rousseau y los philosophes, produjeron tal estruendo que no se llegó a oír el pitido de los silbatos, aquella arma mortífera ideada por Moreau, con la que fácilmente hubieran sido derrotados por los partidarios del orden y de la tradición. En ese sentido, quizás falte por analizar cóno la derrota de los caconacs españoles derivó de la mordaza contra la utopía que se produjo desde los primeros tiempos de Carlos III. La mordaza y el silencio ralpable de aquellos dirigentes que, como dijo Sarmiento, renían sus luces en el mismo lugar que las luciérnagas; aquellos dirigentes que no tuvieron valor para defender sus ideas frente al oscurantismo inquisidor, permitiendo el procesamiento de Olavide; aquellos dirigentes de los que por un momento, solo por un momento, renegó Felipe Samaniego cuando tras la condena de Olavide conlesó que con ellos teía a Bayle, a Voliaire, a Diderot y a Rousseau.

La importancia cducativa del texto que aquí se presenta es testimonial y premonitoria. La úlima frase del último texto pedagógico de fray Martín Sarniento sitúa el problema de las reformas educativas españolas, de ayer y de loy, en sus justos térninos: «si en España hay hoy decadencia de la literatura, también la había en el siglo pasado, pues había el mismo método de estudiar. Y me temo que si ese se muda sin conocimiento de causa, cada día crecerá más esa decadencia». Eso es lo que no entendió el copista, como no lo entendieron sus contemporáneos: el problema de la educación española era un problema de inétodo; un problema cuyas raíces había que buscar en una deficiente formación del prolesorado, que carecía de los más elementales conocinientos en

1" Obore de 660 plicgoss, parágrafos $4478-4481$. 
materias gnoseológicas, de psicología infuntil y de exploración pedagógica y voracional.

Sobre los Estudios de San Isidro, es un corto escrito de 87 páralos, del que no se conscrva el original del benedictino. Tar sólo existe, al menos que yo sepa, una copia, que se encuentra en el tomo VI, folios 283 y siguientes, de la

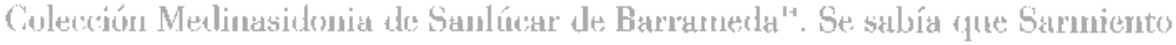
lo había redactado, pero nos era desconocido, porque no lue copiado en la

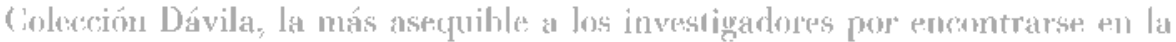
Biblioteca Nacional; y aunque sí debió ligurar en el volumen 6 de la Cioleción Los Heros que guarda la Academia de la Historia, lo cierto es que, cuando la Acadenia adyuirió la colectión en 1860, se echó ya en falla ese tomo. Puesto que la Medinasidonia, primera copia de los escritos del benedictino, y sobre la que se copiaron más tarde las Colecciones Dávila y Los Heros, nu esiuvo al alcance de los investigadores, ya por creerse perdida ya por haber sido confundida con esta última, la reflexión acercá de los Estudios de San Isidro uo

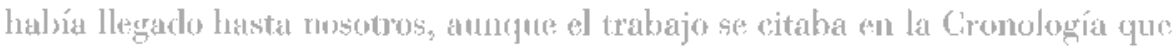
incorpora Pensato en un apéndice de Fray Martú Sumiento, testigo de su siglo"s. También lo titan Cesta y lueceta, Júpez Pcláez y Maria Ángeles Galino". No obstante, ninguno debió conocerlo puesto que no inconporan ningunna cita relativa al texto. Así pues, es la primera vez que Sobre Método de Estudios se publica. Al tratarse de una copia. he optado por modernizar la ortografía. Creo que en este caso el proceder está justificadon yu que el copista no respetó la de Sarmierito.

Quiero agradecer la gentileza y las facilidades que la actual Duquesa de Medinasidonia, la historiadora Luisia Isabel Álvarez de Toledo, y la Directora del Archivo Ducal, Liliame Dahlmau, me han brindado para esendiar y copriar el texio. El trabajo pudo realizarse gracias a una licencia por estudios, de tres meses, y a una ayuda económica equivalente a mis retribuciones como maestro de escuela durante ese período, concedida por la Consejería de lifucavión del Gobjerno de Cianarias.

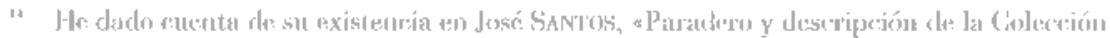

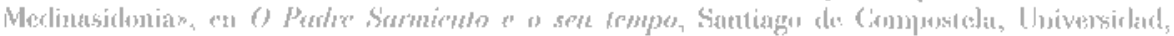
1097. pitgs, 3010-422

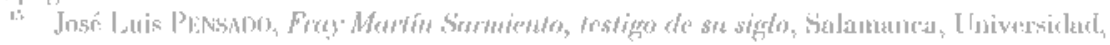
$197^{\circ}$

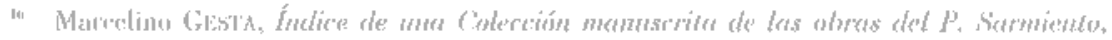

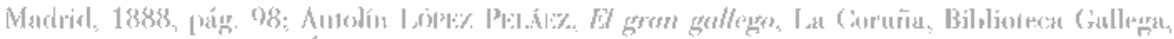

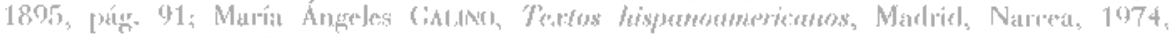
usallmiesm(s), lijilingrafía*. 


\section{«Sobre Método de Estudios}

[ET copista hizo esta introducción al trabajo:] *Aunque en este paped no menciona a autor d sujeto que liabía compuesto d método de estudios solore el rue da su dictamen, se discurre fuese Don Felipe Samanicgo, que estuvo desinarlo por Director de los Reales Esturlios establecidos en San Isideo de Madrid, aumene después se varió y eligieron a otro. Viene a reprobar en sustancia todo d nuevo métorlo, teniendo por más seguro el que se siga el antiguro, con varias mejorías que va señalando de su respuesta.

"1. Hahiendo visto 110 s quince pliegos manuscritos que contienen el Plan de unos Estudios Reales en la Corte, solo por oluedecer y complacer al que ine los ha mandado, los he leído todes de verbo ad verbum. No con aquella atención que acaso pudiera poner hace ahora cuarenta años, pues al presente me hallo ya totalmente impedido en todas las funciones del cuerpo y alma, y del espíritu; y solo hago el papel de un troneo, casi clavado todo el día en una silla que, gracias a Dios, me sufre, anmque con salud y sin dolor.

"2. Pero, por lo que toca a censurar y hacer crítica exacta de ese manuscrito, confieso que ni en mi edad presente, ni en la pasada, nunca he sido capaz de escribir seis renglones con acierts. Nunca he sido narciso de mis trabajos, y siempre he mirado como cosa mejor todo lo que no saliese de mi pluma. El asunto de proponer métorlo para estudios es muy locundo. Hay libros, y en todas lenguas; y se atropellan unos a otros; y se podrá aplicar el proverbio griego de que son muchos los Thirsigeros, pero son pocos los Bacehos. Esto es, no sobra otra cosa pue metodisias y no falia otra cosa que doctos sólidos, y que puedan ensenar a otros.

»3. Si a un millón de cojos y estropeartos se les prescriben reglas para andar bien y con garbo, los más penetrarán las reglas, y todos quedarán cojos. Tan cierto es que los que son cojos o majaderos en la literatura que debe preceder al método, como muchos, que van a países extranjeros a hacerse doctos, ha visto la experiencia que animalia ibant et revertebantur. Diré mucho si dijese que de cien personas que concurran a una aula, saldrán solo diez literatos. Platón advertía que no entrase en su aula, o que saliese de ella, el que no fuese geómetra. 
"4. Sería muy del caso que ninguno entrase en los estudios si, antes, no se examinase de sus talentos para el estudio. Lin esto piensa poco el público, porque no eree que le importa. No piensan los partres, porque, por lo comin. son iliteratos. Ni piensan los maestros, por no perder discípulos y que se ausente el minerval. Cireo que en Atenas había hombres señalatos para que cxaminasen los talentos de los muchachos. si eran para esta o para otra facultad. Y ganaría mucho el público si en España hubiese doctos gue examinasen a los muchachos si eran o no cran capaces para los estudios. De cse modo, st desahogarian las aulas de vantos zángunos inútiles. y se podrian utilizar con las artes mecánicas y en la agrioultura.

„5. Así, debo aplaudir al autor del propuesto Plan de Estudios, por el trahajo que ha querido tomar de formar el método con el que la juventud española se deba dirigir en sus estudios. Alguno alegará, segúu lo dicho, que, ants: todas cosas, se dele arreglar el número de estudiantes; pues siendo excosivo el número de ellos, y en la Corte, serán inevitables mil inconveniencias.

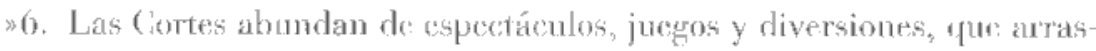
tran y embelesan más a la juventud que todos los gerundios y silogismos. 1 as letras piden retiro y sosiego. No fingió la gentilidad qua las musas habitaban en ciudades, sino en lo más sublime del Monte Pamaso. I dos sabios gimnosofistas habitahan en los montes. Los celtas, para conservar su religión y letras, se retiraban a lo más escondido de los bosques y lucos, inter querras et fagos. I os brachmanes del Mogol, los lamas del l'íbet. los bouzos de la china, y los derviches de los mahometanos, sohre ser infinitos, están esparcidos por los montes y desiertos. Los primilivos monacales, huyendo de la corte de Alejundría, poblaron los desicrtos y montes de la Tebaida, Nitria, Libia, etc. Y los segundos monacales, derivados de aquéllos, huyerom de los poblados y de las cortes para poblar monasterios en los montes y breñas, en donde estudiaron, enseñaron, y couscrvaron la religión carólica y las lexas divinas y humanas.

"7. Carda momasterio era pntomes como una universidad, enmo tulda, San Calo en los suizos, Corbeia, Benchor, ete. Entonces no había más universidades que los monasterios. Será nuy raro el monasterio de monacales que se? haya fundado en poblado, cuando ya estaban introducidos los religiosos mendicantes, excepto San Benito el Real de Valiadolid, que por los años de 1390. fundó Juan I. Rey de Castilla. Los mendicantes cutraron on Enpaña desde el siglo xiI, pero con instituto diferente del de los monacales. El de estos es la vida contemplativa, y el de aquéllos la vida activa. Consistión psto en que los obispos, clérigos y eclesiásticos seculares habían aflojado en la cura de ánimas en los lugares populosos; y así, ha sido conveniente la fundación de las 
religiones mendicantes en los poblados, para la vida activa, y ayudar a los obispos, etc.

¿8. Con esta ocasión, pasaron a los poblados las letras, enseñanza y literatura. No digo que no haya estudios en las Ciortes. En las Ciortes debe haber hombres ya cientificos, que se puedan juntar, no para desparramarse y estudiar o aprender los principios de las ciencias, sino para conferenciar sobre ellos; lo que se debía hacer en las academias, con el fin de promover alguna facultad con inventos útiles. Habrá unos diez años que oí leer una carta de un español muy docto, escrita desde París, en la cual pinta con muchos colores el estado de la actual literatura de París; y, hablando de la lengua latina, decía que esa se había recogido a los claustros. Hablando el autor del Plan de Estudios. pondera la insuficiencia de la filosofía escolástica, y que ya está confinada en los claustros.

„9. Es cierto que esas especulaciones son insuficientes para el que quisiere instruirse de cosas con extensión. Pero sin pasar por aquellas arideces, toda enseñanza será una charlatanería; y siempre será así, mientras todas las religiones no concuerden en señalar los premios en otras facultades más amenas. Ese métorlo escolástico ha durado cinco siglos en los claustros y escuclas, y de ellas han salido a millares los hombres doctos, que han conservado en España purísima la religión católica romana y ortodoxa, cuando los heterodoxos, saltando de aquí para allí, no han dejado herejía que no promoviesen y adelantasen, hasta precipitarse en el abismo de mirar con indiferencia todo género de religión revelada.

»10. El año de 1610 mandó Paulo $V$ que en todos los conventos de regulares se establecieran tres catedráticos de las lenguas latina, griega y bebrea; y si huhiese muchos religiosos, otro catedrático más de lengua arábiga. Manda el Papa que, si en el convento no hubiese tales catedráticos, se traigan de fuera, o regulares o de otras religiones, que enseñen a los religiosos esas lenguas y erudición. De modo que cuando los escolares o estudiantes las puedan enseñar a otros, se entable una sucesión perpetua de maestros y discípulos, como de padres a hijos, y al modo que, de maestro a maestro, se ha seguido la serie de los maestros de las facultades escolásticas, sin salir de los claustros.

»11. Paulo V hace nomoria, en su Bula, de que Clemente V había mandado la misma a los regulares. Pero en los tres siglos tuvo poco o ningún efecto esa deterninación pontificia, porque aún no había premios domésticos para esas habilidades. Hecho cargo Paulo $\mathrm{V}$ de esa dificultad, manda y determina, 
at in promotione ad doctorwhs gradus et ad alios suis ordinis homoris illi, wetersis paribus preparman; qui in cognitione thitm saltem linguamm pratecerint, ita at al illas doomdas apti sumt.

"12, Esta Bula de Paulo V, Ad perpehan rei memoricun, está tendida en el tomo I de la Gmanatica Hebrea del P. Pedro Guarin, benedictino do Sam Mauro. en la pág. 45. No sé qué electo haya tenido esa bulu. Los Santos Padres, griegos y latinos, que el siglo pelsado dieron a luz los benedictinos de San Manro. prucban que Ia dicha bula tuvo acentación eu los claustros cle Paris, en donte se retiró hoy la lengua latina. según el contexto de la carta que he citado.

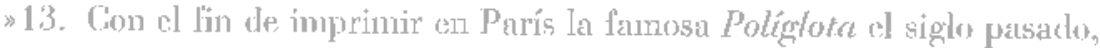
se excitó en París el estudio de las lenguas orientales, pero rluró poco esa llamarda, de fin como furia frumcesa. El año de 1716 sacó Remudot a luz Less Liturgirs Orifntules. Quiso sacarlas en sus originales. pero so queju de cut: no pudo. por lalia de caracteres: typortm defectu. De manera yue los caracteres que habían servirto para la Biblio Políglota. ya se habían echado, conno alicen, al pastel, y se habían peridido del todo.

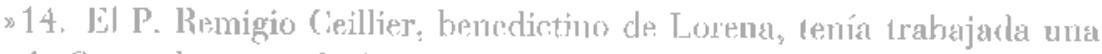
Hisforia Ceneral, pero en latín, desde el ano de 1729 . Ioy son ya 23 lomos cu 4", y on francés, porque no halló impresof gue imprimiese en latín rasa obra. muy nitil para no dejarse imeponer de las libertades de Elías Dupin, que copió de los prorestantes sobre los autores sagrados y ectesiásticos. Concuerda esto con la observación que tengo hecha de que, auncue en Lyon y en otras provincias de Francia, se imprimiesen libros en latín, dentro de Paýs ya no st imprine libro alguno latino. Pregunté a unos que lrecuentan las tiendas de. libreros si habian visto venal algian libro latino impreso en l’arís, y todos ane dijerone c[ur: no le habían visto.

»15. Á́n no ha llegado a España tal decadencia de la literatuna, ni llegará jandás uniwhtras se conserven en los claustros el estudio de las facularles especulativas a las cuales retán amexos los joremios en las religiones. Si viviest un Gasscendo, un Newton, un Gizlileo, un Jeibnitz, y no soturesaliesen en la jerga metafísiod, no indrían dos escotas en su orden, ni jamás seríat prelados. Así, ts hablau al aire formar ryétodos de desamparar las arideces metafísicas de volegios y universidetes, mientras la autoridad pontifieia y real no toman la mano para que los premios de las religiones no estrin guexos, [roreisanente, a dquellas solas arideces. Si éstas. como es posible, se estudian unuy eu breve, sobrará tiempo para que los profesores se dedicfuen al estudio de las

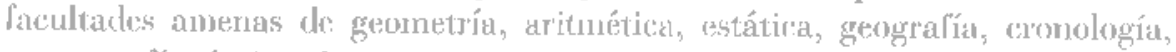
cosmografía, oplio, ética, escritura, c historia natural. 
\$16. El esiudio de las cuatoo lenguas, latina, griega, helorea y aráluiga, no pide tan1o tiempo como se piensa, a 110 ser para sabertas con toda perfección y exiensión. Hsas lenguas, y rodas las demás que andan en las poliglotas, ya son muertas, y hace muchos años que no se hablan. La lengua latina pura es ente de razón, y no es fácil saber cuándo se habló la pura. Cicerón gustaba mucho oír hablar a su suegoda, por el larín antiguo que hablaba. ¡Y qué sería si oyese hablar a una que viviese doscientos años antes? El castellano del poeta Berceo, de la Conquiste de Uhromer; del Arcipreste de Hila, de Juan de Mena, de Lope de Vega, de Solís. y el vulgar que hoy se escribe y se habla, ha venido tumando por más de quiniontos años. El latín más antiguo és el de la Columba Rosirata de Cayo Duilio, que suplió Pedro Ciliacón, y se halla en el Padre Dollato.

»17. İs1a inscripesión es bárbara, y no antecedió mucho al riempo de Ciceron. El autor del Ptun de los Estudios señala scis clases para la lengua latina. Toda ella so dehe reducir a una sola clase, y aúm mozclar con ella, simnel. la lengua griega, quo así se hace en algunas universidades. Esa división de rlases ha sido invención de preceptores, para que los niños ocupen más tjempo. También quieren estableceè en Madrid una cátedra de lengua francesa. Quisiera saber si en Paris hay alguna cátedta de lengua castellana. Y en verdad (jue. según los enjambers de franceses que vienen a España, y que nunca entran bien en la lengua castellana, más necesitan los franeeses de cátedras de castellano en Francia que los españoles de cátedras de la lengra francesa en Madrid.

"18. Soy de dictamen que si hay algún profesor docto y erudito, podrá ensenar, simul, la lengua censelland, latina y griega, pues se dehon reputar las res por una sola lengua, y todas tienen conjugationes, declinaciones y verbos. La lengua latina pura es muy corta k voces: y si le quitan los verbos compuestos y los verbos o nomberes que visiblemente son de la lengrua griega, se quedará al latín en una andrajosa capa de pobre, con andrajos de irregularidarles y anomalías que los gramáticos transliomaron en reglas para sobrecargar a los niños.

\$19. La lengua gricega es inlinita en sus voees, pero muy reducida en sus raíces, o voces primitivas. El año de 1719 salió en París nu libro en versos franceses, que contienen todas las raíces o temas de la lengua jura griega; y som en todas dos mil ciento cincuenta y seis ráces. lá lengua castellana, como es lengua viva y vulgar que se habla y se escribe, en cuanto a voces, es más copiosa que la latina y griega, entrando torlas las voces que innediatamente vienen del latín, y mediatamente del griego, fuera las terminaciones y sin contar las muchas voces que comserva del céltico y gótico, del árabe y morisco, y de las raices indias orientales y occidentales; y que los latinos y griegos no tienen 
110mules propios para significar esas cosas. Comenzando por el estudio de la lengua castellana, debe ser esc estudio el que nás ha de ocupar a la juventud. procmando averignar el origen de todas las voces y de todas las cosas signiticarlas. De este modo. antes de entrar en las arideces metalísicas, se hallará al muchatho fecundado de una singular erudición, que no so enseña en las escuelas ni se euseñará en los Fsumdins Reales, pues se hará cargo de la mitología y de nuchas humanidades, y penetrará mejor la lengua latina y griega; y mirará como juguete las lenguas vulgares frantesa e italiana, y los dialectos gallego y portugués, como derivados del idioma latino.

"20. La terigua hebrea es muy corra de voces, bolo tieno mil veintidós ráces; y de esa cortedad viene la gran dificultad fue hay en explicar el sentido limal de tondo el testamento viejo, no quedando contrxio en hebreo puro, más que ese testamento. Antes de Nabueo, era el hebreo lengua viva, que se hablaha y escribía vulgamente en la Tierta de Promistón. Después de la calntividad de Babilonia, se lizo mutrua esa lengua hebrea, y jantés se habló, ni en tiem-

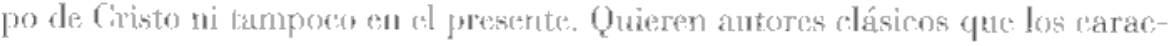
teres que usalon los hetbres antiguos eran los samarianos que hoy usan los asirios, caldeos y babilónicos. I os judios rabinos, para auncrutar el hebreo puro, le han latbarizado mucho, añadiendo infinitas voces bárharas y vulgares de las nutomes en donete residían.

"21. Así, resultó ma lemgua rabina, copiosil y difícil para fuya inteligencia es preciso thexicon felmádico de Buxtorlio. Dice el Sr. Caramuel que en tiempo de Orígenes se esudiaba la lengua hebrea pura en solo ocho dias. No hallo dificultad cu creerlo, según lo corta, concisa y metódica que es la lengua. Todas las denás lenguas están cargatas de anomalías, y como que se lormaron a luulto, solo la lergua santa parece teclado de órgano. No tiente como dije, más que mil veinudós raíces, el mismo núatro de estrellas fijas que. Ptolomeo señaló para el cielo estrellado, antes del telescopio.

"22. Fl alfabeto de los hebreos tiene veintidós letras, y todas sun consonantes. No tiomen vorales, pero se suplen por unos puntitos artificiales, y con los cuales se podvá leor y pronuneiar el texto hebreo de la Escritura; y, sin los cuales, poous lo podrán leer. A un contexto castellano, latino o griego, gúútensele todas las vocalcs, y se jalpará el embarazo para lese ese corntexto. Sobre la antigiondad de csos puntos se levantó una disputa nuy reñida erotre los Buxtorfios y Capelos; éstos, defeudiendo que som modernos y parten do los mahometanos; y los Buxuorfios, que son antiquísimos.

23. Yo soy ded distamen que las lenguas orientales sitmpre se han hatslado y pronunciaclo con vocates. pero que éstas no se eseribíar, sino que los inte- 
ligentes las suplían. En tiempo de Orígenes se escribía el texto heloreo sin puntos o vocales, pues aún no los habían inventado los masorethas, y se estudiaba en ocho días la lengua hebrea, porque había maestros que la supiesen enseñar; y porque si se cargaba de puntos escritos se hacía difícil y muy confusa.. Para que el lector no se aturda de lo que dice Caramuel, sepa que Wilhelmo Schickardo dio a luz en Itrech el año de 1601 un librito cuyo título es Horologium Hebreum*, y cuyo asunto es para que dos o tres amigos aprendan la lengua hebrea en solas veinticuatro horas.

„24. Viendo Mr. Masclel el trabajo que hay de leer el hebreo sin puntos, y la confusión de leerle sohrecargado de ellos, inventó un ingenioso modo de leer el texto hebreo corriente, sin aquel trabajo y sin aquella confusión. Imaginó que las veintidós letras hebreas, cada una significa y que cada una tiene ma o dos vocales en su promuciación, v. g., "lamed» una «a* y una «e», «sohim» una «i», etc. A cada letra del texto bebreo le aplica la primera vocal de la letra, y después la segunda. Es evidente que si los honbres concordasen en esta fácil y preciosa regla, en un instante leería un niño el texto hebreo de la Biblia, sin puntos, con solo saber los veintidós nombres del allabero hebreo, sin hacer caso de los artilicios de los masorethas.

"25. Hay otro tomo, en el cual, a imitación de las raíces griegas, están todas las raices hebreas en versos franceses, y som mil ochocientas raíces. Los judíos nunca usan del texto hebreo sin puntos. Eso pertenece a los rabinos, que escriben sin puntos su lengua rabínica. Y también hay otro tomo de Cenebrando para leer a los rabinos sin puntos. En tim, son infinitos los libros que hay para estudiar la lengua helnea, pero ningunos mejores que los dos tomos en 4" del benedicino Don Pedro Guarin; pues, además de que trata también de la gramática caldea, el segundo tomo todo es de erudición hebraica, muy precisa para un literato eclesiástico, y regular. Por eso Paulo V encargó tanto el estudio de las lenguas sagradas, porque los herejes cargaron la mano a esos estudios.

"26. La lengua arálsiga, en cuanto a la gramática, es cosa muy corta; y el que supiere ya la lengua hebrea, entrará sin dificultad en aprender la lengua arábiga. Todas las letras de su alfabeto son veintimueve consonantes. Tampoco

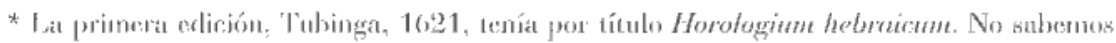

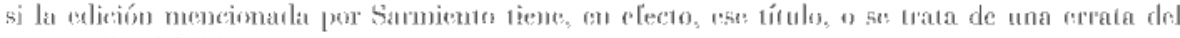
copista ( $N$, dellis.). 
liene puntos o vocales, por lo gue es muy difícil leerla, hablarla, y aún enredoso el escribirla, a causa de que se cncadenan las letras. Hay esta grave dificultad para los principiantes que quieren estudiar las lenguas arábiga y hebrea sin puntos: El que anves no supiere bien la lengua hebrea y arábiga, janás las sabrá leer y hablar; y para leerles bien, véase en doucle está el ropiezo para las orientales: 10 se puederu lexer sin puntos, si, antes, no se saben leer; y jamás se sabrán, si, antes, no se saben leer sin pruntos.

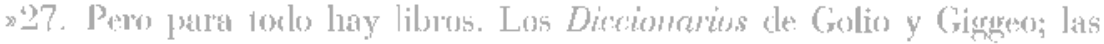
Cramácices de Expenio, Marteloto. Metorata, etc. Y el Focabulario AnábigoCastellano del P. Alcalá, te. No solo sirven para lengua, sino también para la crudición oriental. No dethe entrar estudiante en las especulaciones metalisióds si, antes, no está nedianamente insuruido de las erudiciones castellanas, latina, griega, hebrea, rabínica y arábiga, etc., y sin una merliuna noticia de los libros y geograllía, elc. Hay muchisinas voces en el lastellano que son de origen arábigo; y unal se podrá hablar del castellano, si no hay alguna noticia del arábigo.

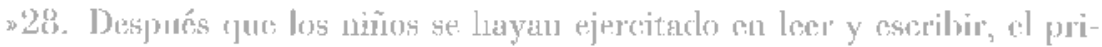
mer ruidado de ellos deloe ser la geligión y las buenas costumberes. Solo deben ejorejiar su menoria en la foctrina reristiana y en las oraciones de la loglesia.

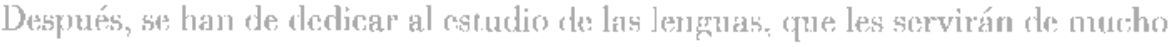
para lo adalanta: lemgua castellama. lengua latina, gricuga, hetrea y aráliga, para rumplio con la Bula de Pauln V cle 1610. Proberé con cxtensión que sin un conocimiento exacto de la lengua castellank y del origen de sus vocess, todo estudio irá fundado en el aire y pegarlo com oblea. Ho ratado a muchos rloctos y graduados que tin poco sabían de la lengua castellara como de la rnora. Si

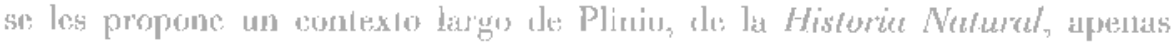

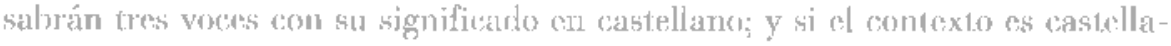
no, titubearán en señalay los latines corespondientes. No hay lombres que menos sepan la lengua castcllana con extensión que los profesores de ciemeias espoculadivas. Les pajece quo con su latín bárbaro de las escuelas, no vecesitál salyel más latún, ni castellano.

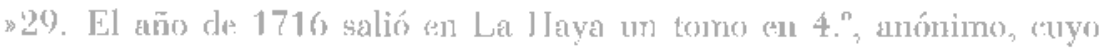

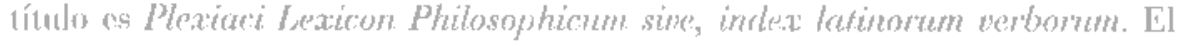
asunto es al modo de hablar latín porto y ciceroniano en las escuedas, para desverrar en ellas la badmarie semoncestraila, que tasto la durado. Este vomo se debía reimprinir an Madyid, y repetirle por los preceptores de España. Y no habia de haber médico, teólogo y jurista que no le tuviese, para habiburse at

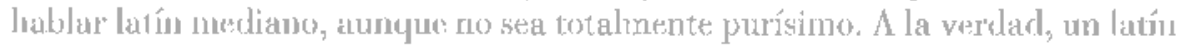
purísino, pasaria por un harharismo de otra cspecie. Los antiquísimos latinos 
no nos hau dejado voces para la décima parte de las cosas. Y ese delecto os común a todas las lemguas que ya som muertas.

\$30. En ellas, apenas hay voces que correspondau a las cosas individuales; y memos a las voces vulgares. No admiro que esto suceda con las cosas artificiales, que de un día para otro se mudan y se alteran. Pero es de exurañar que lo mismo suceda con las cosas naturales, que siempre son unas mismas e inalterables; soy, purs, del dictamen que la gramática vulgar, o castellana, se les enseñe a los niños antes de enseñarles la grautática en latín. Lo nismo, a proporción, digo de lodus las demás artes y ciencias: que será bueno se les cnscñe primero en la lengua vulgar y será más fácil penetrarlas luego en lengua latina.

231. El que está muy instruido ya en la lengua latina y su gramática, os experiencia que en breve liempo se hace capaz de la lengua griega; y es conseeuencia que, para esumdiar en breve la lengrua latina, se debe estudiar antes la gramática y lengua castellana. De modo que las tres lengruas, castellana, latina y griega, se deber mirar como una sola, y para una sola aula, y para um mismo maestro. No así la lengua heturea, que esa tienc otro género de gramática. Pero al que llegase a estar instruido de la gramática y lengua helorea, ya está proporcionado para entrar en la lenguat arábiga, y en olras lengruas orientales. como caldea, siríaca y persiana, pues todals se escriben y se leen al revés. Y todas carecen de vocales, etr., como la hebrea.

\$32. Lo que he propuesto para las lenguas digo que también se debe hacer para las cioncias o facultades mayores, explicándolas primero cn lengua vastellana y después en lengua latina. El pintor que quiere pintar un cuadro perfecto, primero se ensaya en dibujar cru rrueso y tosco carbón, lápiz de: representación; y despues, hare lo mismo con colores y de úlimua mano. No hay cosa más fácil que format un libro en castellano, que sea borrón o dibujo de las Summulas, Lógica, Metafísica, Filosofía, etc., segrín se enseñan en las csevelas, con todas sus arideces escolásticas. Y lo mismo se podrá hacer con las demás ciencias y arles, estudiándolas primero en compendio en castellano y despues en latín, arreglado al citado bexicon de Plexiceo, del ns." 29. De ese: modo, y col breve ticmpo, y digo en un solo año, ahorrarán los muchachos a estudiar de memoria y a la letra lo pue ni han entendido, ni entenderán; y usarán de un latín inenos bárbaro.

\$33. Al principio de este siglo era muy común un libro con el título Margarita Philosophica, en 4." y en latín. Fra como un compendio de dodas las ciencias, y el que le venía créía que tenía la piedra lilosofal. Yo no cré tanto. Después, no he visto ese 10 mo, pero he visto otro con el mismo título, y en $8 . "$. impreso en Nuremberg. Dice así el título: Margarita philosophica in anmolo 
sine sinopsis totius phitosophia, ita dispositus at annus spatio discentibus commode proponi, et exphorat posst. Lil autor es Andrés Reyher, rector del colegio de Hemeberga. Se divide en diecinueve disputariones o compendios, $t \cdot g$, desde la metafísica hasta acabar con una enciclopedia a doctrina en círeulo.

"\$4. J Lo más respecial consiste en que mu muchacho, sin ocupar nás que un solo año, podrá saber más y mojor las cosas que unos catedráticos de escuela. A imitación de esa Margenta se debía formar un tomo en 8" y en castellano, que compremela los mismos diecinueve iratados, y que d umchache debe leer y releer, sin estudiar de memoria y a la letra. Después, entrará, como por su casa en la Margenita latina o en otro curso de ciencias. Y se fecundará de voces latimas y castellanas prias. Paréceme que este método de costudiar cosas en latín, después de haberlas lédo en caste!lano, es el más apropiato palta coludiantes espanoles; y que, por falta de ese antecedente, no ha hecho la literatura en Isspaña

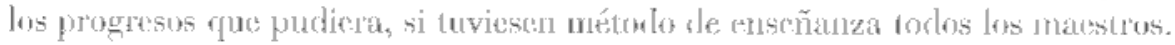

335. En esa Margatita is Annolo hay epítome de Arimuérica, epitome de Geonetría, epítone de Lstática, epitome de Astromonía, opítome de Oprica, epítome de Astrología, epítome de Mísica, ete. y mada de esto se estudia ni se cuseña en la escuela de silogismos. Y yo aseguro que sin aquellos epítomes, leídos en castellano, nada se sabrá en las escuclas con funclanento. Así, después del ejercicio en las vinco lenguas, se ha de segnir un año entero en el cual se

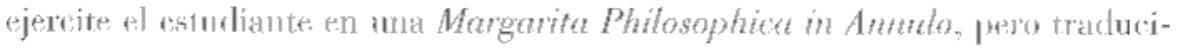
da al castellano, con el fin de recoger nuxhísinas voces castellanas pulas; y las latinas correspondientus.

336. Por esa Margatia in Amndo dehen comenzar los niños sus esndios cienrificos, hasta que lleguer a ser autodidactos, o que a sí mismos se ansenen, y es el medo de librarse de matestros rapares e idiolas; y de otros, ancianos, gue rienen más años de ignorantes. El que ha de ser maestro de la eclucación de la

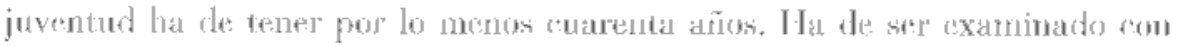
wodo rigor, y se dehe pscoger nl más aventajado en la lengua estellana, latina, griena; y due tenga algunos principios de la hebrea y la arábiga. Ta de tener noticia de forlo género de libros conducentes a las ciencias que ha de enseñar. Som infinitos los libros cue hay, y que cada día salen a la luz, prara saber y saber enseñar a la juvenud la gramática y todo género de artes y ciencias, ya especulativats, ya prácticas. Do un niño que frecuentemente trae debajo del brazo un vadenécum o cariapacio, sacamos que frecuentemente va a la escucla de escribir y del que trae debajo del brazo muchos libros de gramática decimos que freenenta la aula de latinidad. Y los rústices dicen de sus hijos que som muy doctos, porque ya traen muchos libos debajo del lorazo. 
„37. Esos libros más exquisitos, que sirvan para la educación de la juventud, podrán formar una bibliotequilla de niños. Juan Gristóforo Wagenseilio formó esa bibliotequilla y la llamó Pera librorum juvenilium; o alforja, zurrón, maleta y bolsa de libros para los niños que han de estudiar. Son catorce tomos latinos en $8^{\circ}$, y es un juego muy curioso que se imprimió en Norimberga el año de 1695. No sé si ese juego de catorce tomos será venal en Madrid. Yo pondré aquí su compendio:

\section{Tomo 1. ${ }^{\circ}$ de la Pera Juvenilis}

1.") Trata de particulis latinis sermonis

2.") De las Fábulas de Fedro

3.") De los libros de Quinto Curtio

4.") De las Epístolas de Plinio al junior

5.") Excepta Ciceroniana

6.") Gnomae Ilustres veterum sapientum

\section{Tomo 2. ${ }^{\circ}$}

1.") Precepta artis retoricae

2.") De poesi germanicae

3.") De poesi latina

4.") De copia verborum

5.") Precepta de Stilo

\section{Tomo 3."}

1.") Sinopsis Doctrina spherica

2. Praecognita geographiae

3.") Ummonica Geographica

4. $\left.{ }^{\circ}\right)$ Sinopsis Geographicae

\section{Tomo 4. ${ }^{\circ}$}

Sinopsis Geographicae

\section{Tomo 5. ${ }^{\circ}$}

1.") De mithologia veterum

2.") Praecognita Historia

3.") Mnemónica historia

4. $\left.{ }^{\circ}\right)$ Sinopsis historiae universalis

5.") Nomenclator regnum et principes europae

\section{Tomo $6 .^{\circ}$}

Historia Universalis

\section{Tomo 7.}

1. $\left.{ }^{\circ}\right)$ Synopsis Logicae

2.") Methodus disputandi

3.") Synopsis ethicae

4.") Synopsis economicae

$\left.5 .^{\circ}\right)$ Synopsis politicae

6.") Synopsis phisicae 
7.") Synopsis artis valetudinis

8.") Synoysis metinhisicate

Tomo 8."

1.") Ars valeudinis

2.") Ars bonae mentis

3.") Synopsis metaplisicae

4.") De angelis, Deo et Anima

Thomo 9.

1.") Symopsis instiutionum jurtis

2." Digestorum libri

'Tomo 10."

1.") Explicatio rubicarum codicis

2.") Synopsis juris feutalis

3.") Synopsis juris anonici

\section{tome 11."}

1.") Analecda de Doctrina et ritibus romanat cedesiat:

2.") Regulap mriusqut: juris Lapuldinat

\section{Tomo 12."}

Synopsis historiat miversalis, parsi altera

\section{Tomb 13."}

Symupsos historiate miversalis, pars. 3"

\section{Tomo 14.}

Historia universalis

\$38. Estos catore tomos de la Pera Juenilis comprerden cuarenta y tres rratados, a imitación de la Margario Philesophica in ammolo, que he ritado de Reyher. Y es créble que unvese presente a esa Margarita Cihristóloro Wagenseilio para formar su Pere Jumenilis. Principalmente consiste en que Wagenseilio escribió para educación de su hijo. Pareció hien a todos, y así, se imprimió para ubilidad del Público. Ls eviderute que lá Margerita se esoribió para la educación de un niño, y lo mismo digo de los catorce tomos citados.

\$39). Ayuí so me ofrect un pensamionto para el Método de Estudios. V os que, para la perpenuidarl de los estudios, se deleen comservar de padres a hijos. Tha de las conses de la deeadencia de la literatura en España consiste en 'fue las artes y ciencias 110 so transmiten a la posteridad de paches a hijos. Hay tom-

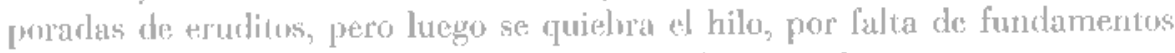
sólidos y constantes. Suponganos que un padre muy docto toma a su cargo enscñar a su hijo; éste ya podrá enseñar al nisto, y éste al bisnieto, y así suctsivamente. Las cioncias especulativas, que tanto se han conservado, conservan y conservarán en España sin decadencia alguna, consiste en que se enseñan y 
transmiten de padres a hijos. No padres naturales, sino padres morales, cuales son los religiosos respecto de unos y otros.

»40. El españolito del cual habla el Ilmo. Feijoo en el tomo $4^{\circ}$ de su Teatro, y que tanto ruido metió en París por su temprana y prodigiosa literatura, todo lo debió a la educación que le dio su mismo padre natural. Es muy otra la enseñanza que puede dar un padre, si es muy docto, a su hijo, que la que le podrán dar los pedantes pedagogos y maestros de aulas. La enseñanza que un padre da a su hijo se debe comparar con la leche que la verdadera madre da a su infantico. Es indispensable que, siguiendo el orden natural, la madre aleche a sus hijuelos y que el padre los instruya en las habilidades de su especie. Y no se ha visto en el mundo que los animales busquen amas de leche para sus hijos, ni que un gato padre busque otro gato que enseñe a sus gaticos a cazar ratones.

»41. Aquella barbarísima costumbre, que se lee de algunas naciones, que, cuando la mujer estaba parida, no ella, sino el marido, se echaba en cama y allí le asistían y regalaban, como si fuese la parida, no puede ser más bárbara. Рог lo mismo, he discurrido que, siendo tan común, ha tenido algún útil fundamento. Dicta la razón que la parida dé la leche a sus hijos. Y ya Aulo Gellio declama en el libro XII contra el intolerable abuso de buscar amas extranjeras, a no preceder una enfermedad contagiosa o que la leche de la madre se vicie del todo. Supónese que así la leche de la madre y del ama se viciarán si alguna de las dichas tiene congreso con varón. Así, se pone cuidado en que las amas vivan castas.

»42. Para que la parida viva casta y se abstenga por algún tiempo, no se puede discurrir cosa mejor que el que el marido separe cama y que en ella haga de enfermo y le regalen. En los países en donde está en uso la poligamia, es excusada esa bárbara ceremonia, pues el marido podrá habitar con otra mujer sin tocar a la parida; y ésta tendrá tiempo para alechar y cuidar de su hijuelo. Con la leche de la verdadera madre se debe alimentar el hijo, y éste se debe educar con la doctrina del padre o tío, o de algún pariente cercano.

*43. La viva voz del padre, como maestro, es más segura, eficaz, y de más prontos efectos que la voz viva de un extraño que no haya mamado la misma leche que el niño. Esto de buscar ayo o maestro, o pedante o pedagogo, para su hijo, es el mayor de las necedades entre las modas. Se burla Juvenal de los romanos que pensaban traer retóricos de la Isla de Thule.

"44. Todo maestro que no haya mamado la misma lengua que el discípulo, no debe ser maestro en España. Sea éste o el otro extranjero, será sus- 
pecta fudei; ¿y qué costumbres y doctrind católica enseñará éste al niño? ¿Qué lengua vulgar le enseñará? ¿Qué culto divino y prácticas morales y etiquetas de buena crianza, a la española, le podrá enseñar el que es ajeno a todo esto? No entro en los vicios morales, pues, siendo la borrachera el vicio trascendente a todo extranjero, se podrá inferir cuáles serán las virtudes de ese mamacallos y zampatortas. No me opongo a que si algún extranjero tiene alguna habilidad mecánica superior, se admita para enseñar en España.

45. De la historia literaria consta que ha habido muchas familias literatas. Los Manutios, Buxtorfios, Capelos, Stephanos, Menckenios, Muratos, Meursius, Vossios, Bernoullis, etc., todos han sido literatos porque estudiaron sin salir de casa, sin patear ni vocear en las aulas ni en los congresos literarios. El modo, pues, de que la literatura se conserve en España, y que dure bastante tiempo sin decadencia, ha de ser introduciendo el que los padres sean los maestros, y que la ciencia pase de padres a hijos, nietos, etc. Hágome cargo de que no todos los padres son capaces para enseriar a sus hijos. Sepárense los que, en virtud del examen, son incptos para las letras, y los que son hijos de labradores y artesanos; y de ese modo será moderado el número de los niños que podrán ser discípulos de sus padres.

„46. Los del Indostán tenían ley inmemorial, como consta de Estrabón, que dividian en dos clases a todos los vivientes; en la primera, se colocaban todos los sacerdotes, y los llamaban filósofos, pues de padres a hijos conservaban la religión y las ciencias. En la segunda clase, colocaban a los labradores, los cuales estaban exentos de ir a la guerra, etc. Y con razón, pues la guerra es la polilla de la agricultura y la ruina de los agricultores. Por eso, los del Indostán ocurrieron a esa necedad, mandando que ningún artesano tuviera otro oficio que el de su padre. Los hebreos, que dividían la nación en doce o trece tribus, separaron toda la tribu de Leví para el sacerdocio, y, como se casaban, turnaba el sacerdocio de padres a hijos.

47. Es evidente que si los que trabajan en piedra, madera, hierro, metales, tejidos, cueros, agricultura, piscicultura, etc, se conservasen siempre de padres a hijos, esos empleos siempre estarian e irian en aumento y en perfección; y jamás podría haber decadencia de esas y de otras semejantes artes.

„48. Lo que digo de las artes mecánicas, se debe entender también de las artes liberales y de las ciencias especulativas y prácticas. El whle tolle de los modernos contra la utilidad de la lógica, metafísica y física de las universidades y de los claustros de religión es una tirria solapada, porque no han sido para esos estudios y quisieran que se desterrasen del mundo, para hacer lugar a otros estudios más porfiados e inútiles. ¿Qué tiempo tan mal gastado como 
el que se gasta en porfías gramaticales, en retórica, en poesía? ¿Y qué ganó el Público con esos estudios de pura charlatanería? El siglo pasado se perdió bastante tiempo en poesía vulgar, y, al mismo tiempo, se perdió Portugal, el Brasil, todo el Oriente, Cataluña, y casi toda la Flandes y mucha parte de las Américas. Todo se remediará si, después que los estudiantes han acabado su curso de lógica, metafísica y física especulativa, se divierten en leer la Margarita Philosofica in annulo y la Pera Librorum Juvenilium.

„49. No habrá asunto del cual no puedan hablar con formalidad y precisión, lo que jamás podrán hacer los que solo leen elenchos de libros. Para reformar el latín, se debe manejar mucho el citado libro Lexicon Philosophicum de Plexíaco. Con esos libros se dará insensiblemente el estudiante escolástico a leer otros libros de varia erudición; y, sobre todo, de historia sagrada y profana, sin dejar de la mano la Biblia con un ligero comentario.

»50. Así, las ruidosas alharacas contra la pretendida decadencia de las ciencias en España se emplearían mejor contra la disciplina militar y su decadencia; si se comparan las empresas de nuestros antiguos españoles con las que los de hoy han tentado en nuestro siglo, se verá la diferencia. Si la literatura presente de España se compara con las de otras naciones, y repasando el siglo por siglo, se palpará que las naciones que más nos cacarean, no han muerto más moros que los españoles; y que no han hecho tanto como ellos en la literatura. Para hacer el justo paralelo, se necesita más tiempo y lectura que el que yo tengo de presente.

»51. Dejo a un lado el tiempo de los romanos gentiles, en el cual vivieron Columela, Higinio, Quintiliano, los dos Sénecas, Lucanum de Córdoba, Ossío. San Dámaso, y Prudentio, Paulo Orosio, etc. Y en tiempo de los godos los cuatro hermanos santos y doctos: Leandro, Fulgencio, Isidoro y Florentina. A los godos se siguieron los moros y judíos españoles; pero todos muy eruditos en su religión y lengua. Los judíos más estimados de los mismos judíos extranjeros, son españoles; y sus códices, los más correctos. Los moros, en Córdoba y en Toledo, plantaron escuelas de matemáticas; y los franceses venían a estudiar a Córdoba; y hay un libro de poetas árabes de Córdoba, que se debía traducir, pues se reduce al siglo nono. Y así, los cristianos españoles se dedicaron entonces a la poesía árabe.

„52. El siglo XIII ha sido muy famoso por tres cosas que tocan a la literatura floreciente de España. Primera, por la publicación de las Leyes de las Partidas. Segunda, por el Decreto del Rey Don Alonso el Sabio para que todos los procesos se escribiesen en lengua castellana vulgar, y que a ella se tradujesen diferentes libros latinos y de otras lenguas extrañas. Y la tercera, porque $\mathrm{cl}$ 
mismo Rey Don Alonso el Sabio, ayudado de insignes astrónomos egipeios, moros, judíos y españoles, compuso las Tablas Astronómicas que hoy llaman las Tablas Alfonsinas. Y esto, sin telescopio.

»53. EI siglo XIV ha sido el siglo de las Crónicas de los Reyes. Y Pedro I ópez de Ayala tradujo muchas obras del Bocaccio, y a Tito Inivio, ctc. El siglo xy se formó en la Corte de Juan II de Castilla ura como Acadenia de hombres doetisimos, como Enrique de Villena, Juan de Mena, Marqués de Santillana, Alonso de Cartagema, el Comendador Juan de Lucena, ete. Y, en fin, vivió entonces el Abulense, que escribió tamto y tan bien. $Y$ a la mitad de ese siglo vinieron de Constantinopla hombres doctisimos de la Grecid, huyendo del urco, y se establecieron en Italia y allí restauraron las lowas, que estaban perdidas, aunque ya el Petrarca había comenzado.

„54. El siglo xv ha sido el siglo de las Biblias Poliglotas, o impresas en muchas lenguas con sus propios caracteres. La primera y más famosa ha sido) la Polightota de Alcalá, en tiempo de Cisneros. Para ella se juntaron murhos pepañoles doctísimos en varias lenguas. Entre ellos, ha sido Antonio Nebrija el restantador de la laninidad en España. Y los fetnceses se valieron de su Arte, y le reimprimieron en Lyon, y en francés, en el año 1548, para esudiar por él la gramáticoa.

„55. En el mismo siglo se imprimió en Antwerpia la Polígtota que llaman Regie, porque la costeó Felipe 11, y que dirigió Arias Montano, con cl texto siríaco que no habia puesto la Complutense. Com oxasión de csas dos Políglotas. salieron de España muchísimos hombres grandes, doctos en todo género do literaura, lenguas y erudición. He observado que, cuando por este o el onso acaso, se levanta una lechigada de hombres doctos, dura poco más o momos unos cien anos, pues, o signe otro tanto tiempo de barbarie y cemata la literatura, o degenera en fruslerias, pedantismos y charlatanería.

„56. No se me ha ofrecicto otro modo de olvidar esa casi elímera luración sino el que las ciencias se propaguen de padres a hijos, nietos, ete que vinculen a tal y tal familia docta y noble de las que tienen y poseen in perpetum 111 mayorazgo. Poco se adelanta con un método de estudios si no se logra que. ese sea perpetuo y dure por muchos siglos. De algunos árboles se cuenta que han durado muchos siglos sin decadencia alguna; y esto solo por el continuo cuidado de un emnitaño deroto, y que esa cultura pasó de padres a hijos. Ya dije, con Estrabón, que la agricultura en el Indostán se heredaba de padres a hijos, y que el labrador no podía mudar de oficio. Herodoto, muy anterior a Estrabón, reliere lo mismo que Estrabón de los egipeios; y añade que también la milicia se cnseñaba de padres a hijos. 
»57. En el libro $2^{\circ}$, desde la división 164 , de Herodoto, está la división de todos los egipcios en siete clases. La primera es la de los sacerdotes; otra de los pugnatores o militares. De estos, ciento sesenta mil se llamaban hermotybios y doscientos cincuenta mil calasirios, y ningún militar podía ejercer oficio mecánico ni de pane lucrando, "sed solum rei militari, filio descenti á patre". Eran todos los soldados cuatrocientos diez mil. De estos, cada año se separaban mil hermotybios y mil calasirios para asistir al Rey en su Corte, y el Rey les debía sustentar allí, asignando a cada uno doce aruras de tierra y doce fanegas de sembradura, y con las viandas correspondientes de pan, carne y vino. Así, iban turnando dos mil cada año para asistir a la Corte. Los demás estaban divididos por sus provincias y residían en sus casas, enseñando a sus hijos la disciplina militar, como nobles y caballeros, y estando prontos para ser soldados.

»58. Esos mismos serían doctos en las artes liberales, para enseñarlas a sus hijos también. Así, las ciencias y la disciplina militar se conservaban de padres a hijos, sin decadencia alguna. Con este sistema, se excusaban los soldados arreglados y las tropas auxiliares, que solo sirvieron para arruinar el Imperio de los Romanos y de otras naciones. Después que en España se aplicaron a la guerra los granaderos provinciales, éstos se portaron mejor en las funciones militares que las tropas arregladas, muy peinadas y muy bailarinas.

»59. Paréceme que el Rey de España podrá tener en pie cincuenta mil soldados caballerosos y que, por lo común, están ociosos, sin oficio ni beneficio. Con esos caballeros y con la milicia de a pie, se podrán hacer tres círculos a toda la península de España para que esté perpetuamente impenetrable a todos sus enemigos, sin salir de sus casas. La respuesta del Oráculo a los atenienses, que estarían libres de sus enemigos si hacían a Atenas una muralla de madera, aludía a que deberían rodear Atenas con diferentes escuadras de navíos; y no será difícil que en España se puede hacer lo mismo con embarcaciones de todo buque, que trafiquen y que vayan y vuelvan a la América.

„60. Repartidos los cincuenta mil caballeros por toda España, en sus casas y patrimonios, para alimentarse, se han de separar dos mil caballeros cada año, para que turnen y asistan en la Corte del Rey; y que el Rey los alimente. De este modo, será poco gravosa al Rey y a los pueblos esta milicia. Y, procediendo esta de padres a hijos, será eterna. Los caballeros han de estudiar las artes liberales (lingua, tropus, ratio, numerus, tonus, angulus, astra) para saberlas y enseñarlas a sus hijos con la disciplina militar; y yo aseguro que no habrá, en ese caso, decadencia ni en letras ni en armas.

»61. No soy de los que creen que uno es docto porque posee muchos y selectos libros. Ya en tiempo de Luciano había esa añagaza para hacer papel 
de docto. Y él escribió contra uno de esos indoctos enmascarados Adversus indoctum et libros miltos ementem. Soy, sí, de los que deben creer que el que no tiene libros propios ni ajenos, ni puede ser docto, ni aúm semi-docto. También es precisa una buena elección de libros, para no confundir las cosas.

„62. Supongo que todos los caballeros militares tienen um mediano mayorazgo y patrinonio para comprar algunos libros para las artes liberales y paru la ciencia militar; rada pardre de familis militar, o por sí dirigido o por otro, debe de ir comprando libros para su enseñanzá y para la de sus hijos, nictos, etc. De modo que, con el tiempo, la familia tenga su mediana biblioteca incorporada en el mayorazgo de la familia, sin que se pueda enajenar de ella en ningún caso. De ese modo, habrá muchos millares de familias literatas en España, y con los libros correspondientes.

„63. El primero de la familia debe enseñar por sí mismo al hijo, y éste a su hijuelo; y así por una continua succsión de padres a hijos. Y solo con esta providencia, no habrá decadencia en la literatura española. Esos caballeros seglares no deben meter su hoz en los estudios sagrados, propios de los sacerdotes, como no la metían entre los del Indostán y de los egipcios, y de otras naciones muy cultas. El mismo Dios ha presto una barrera entre los estudios de religión y los estudios profauos. Ya se hubiera acabado la verdadera religión si no hubiese esa barrera y, en breve, darían en tierra el Fstado y la Monarquía si se diese lihertad a los profanos para sucharetear de las cosas de religión.

w64. Sé que los monateomachos solapados de hoy, y que tanto aspiran a la total independencia, acometieron a los Revellines exteriores para establecerse en un libertinaje vicioso y soltar las riendas a todos los vicios. A tanto nunca llegaron los gentiles, ni los paganos más pagauos, y ni aún los idólatras más idólatras. Tal cual, sumamente malvado, apuntó algo de lo dicho, pero los concilios y el público impidieron que pasase a dogma, y se debe temer que pase a dogma en donde se imprimen, se aplaudern, se venden y set lucinan ese género de librejos pestíferos.

"65. In que conviene es que esos caballeros, padres de familias, los eclesiásticos, seculares, y todos los religiosos, enseñen a sus hijos o a sus sobrinos como han enseñado en tantos siglos. La lógica, metafísica y física escolástica no han viciado la religión revelada. Y se nota que los profesores que no han pasado por aquellas arideces, se les conoce a la legua, que no saben formar un discurso formal y limpio, ni saben sacar una consecurncia con acierto.

\$66. Ya dije que todo eso se podrá componer con un papirote; no desamparando esos estudios de universidad, sino separando dos o tres o cuatro años 
en los principios, para instruirlos en otras ciencias menos áridas. La Margarita Filosófica In annulo y la Pera Librorum Juvenilium sobran para instruirse medianamente. Se debe huir de todo método que proponga algún pedante pedagogo o preceptor que ha de vivir de eso, o que sea de pane lucrando. El que ha de enseñar a otros, ese mismo debe inventar el método de estudios. Los seglares se han de aplicar por vida a la Historia Profana. Y los eclesiásticos a la Historia Sagrada, Biblia, Concilios y Santos Padres.

„67. No hay que suponer que el padre de familias ha de tener siempre algún mayorazgo que siga la literatura. Tal vez no será para ello. En ese caso, si tiene muchos hijos, el padre escogerá otro hijo de conocidos talentos para el estudio. Y, a falta de hijos, debe echar mano de algún sobrino o de algún pariente muy cercano a la familia, el cual, aunque no lleve el mayorazgo, siempre ha de llevar la biblioteca, que ha de ser perpetua en la familia; y así se perpetuará en la misma familia la literatura en España, y sin decadencia visible; y si hubiese alguna, con facilidad se podrá restaurar.

„68. No sé si alguno habrá pensado en ese arbitrio. Los americanos, que no tenían letras ni escritura, no tenían otro modo de transmitir a la posteridad sus conocimientos, noticias, virtudes de mixtos y otros secretos, sino por tradición oral de padres a hijos; y lo mismo sucedió con las falsas supersticiones de su falsa religión. Así, se propagaban sus historias por tradición de padres a hijos. Poco importa que, de ese modo, se alteren las historias, pues en las naciones que tienen letras y escritura, hay historias falsas y tradiciones ridículas.

„69. Lo más es que así pasaba de padres a hijos la lengua natural, y así se conservó y conserva: únicamente al oído mediante el padre y la madre. No es mucho que un oficio mecánico se propague de padres a hijos, pues los niños son naturalmente remedones y monos de todo lo que ven. Y es natural que, de solo ver, aprenda el hijo el oficio mecánico de su padre, y aprenda la lengua de su padre y de su madre con solo oírlos hablar, sin maestro ni pedagogo, sin universidades, colegios, academias, y sin estudiar cosa alguna de memoria y a la letra.

* 70. Leí en una epístola de Nicolás Clenardo el modo de enseñar a un niño la lengua latina solo al ó́do y sin estudiar de memoria. El maestro no ha de hablar sino latín, y el niño ha de repetir la misma frase; y así, sirviendo a la mesa, con el tiempo, sabrá latín y castellano. Después de esa epístola de Clenardo, será bueno leer la Exercitatio Dialogística Linguae Latinae, con las anotaciones de Pedro de la Mota, sobre Luis Vives; y con un índice castellanolatino de Juan Ramírez, en Alcalá, 1658, en octavo. A este tenor, hay trescientos librejos para enseñar latín, pero falta uno para que los niños quieran estu- 
diarlo. Y, en especial, en la Ciorte, en donde no debe liaber estudiantina, habiendo tantas diversiones y siendo ocasionados a bullición y tumultos.

"71. Por cso Fehipe V desterró de Barcelona la estudiantina y lá colocó en el despoblado de Cervera. Cada niño, pues, de la Corte no debe salir de la vista moral y física de sus padres y parientes. Aún los más rústicos se arlmiran de ver que un calesero que ha viajado a París sepa de vuelta la lengua francesa sin libros ni maestros, y que se necesitan tantos adminículos para saber la lengua latina. Lá culpa la dioncn la chusma de preceptores, que no saben latin ni castellano. Estoy firme en que para estudiar el latín, es preciso estudiar antes el castellano y su gramática; y que esa lengua jamás se sabrá con extensión si. antes, no se recogen todas las voces castellangs que tocan a la Historia Natural. En esto ninguno ha pensado, porque: ningún estripagemendios piensa en saber la Historia Natural en sus tres reinos, y esa es la clave de toda ciencia.

\$2. Estoy aturdido de que, habiendo tantos escritos de la lengua latina y de la gramática, no se haya pensado en lo principal por donde se debe comenzar a estudiar una lengua. La lengua latina, que tanto ruido ha merido en las escuclas, ticne más lacras que una hurra vieja ya matada. Primeranente, respecto de Cicerón, era muy moderna, pues el contexto antiguo que se cita es la inscripción de la Columma Rostrata del tiempo de Cayo Duilio. Fn segundo lugar, es muy diminula de voces, y muy ropiosa de anomalís. bi se adiende a estas, se podrá decir que la letrgua latina muncé ha sido constantie, y que do cincuenta en cincuenta años se alteraba aún más que la framcesa. La variedad que tiene en los géneros y pretéritos prueha que no tiene un origen fijo, a no recurrir a la lengua griegá.

"73. Lis crror creer que muchas voces que se usan en escritores latinos posteriores 10 son latinas puras porque no se hallan en los eserivores antiquísimos. Siendo cierto que ya se perdieron muchos libros muy anteriores a Ciccrón, ninguno podrá decir que esas voces no se hallaban en esos libros perdidos. Con esta solución, va por el suelo la charlatanería de los pedantes gramaticastros, que malbaratan el tiempo en esas discusiones, aporreando a la juventud con el daca latín puro y toma latín puro. Los que tienen idtéd do algunas lenguas vulgares que, sin duda, son dialectos de la lengua latina, tropezarán con las voces vulgares, cuyo origen manifiestamente es una voz purísina latina.

74. Asi, esos İatinistas gue no satem los dialectos derivados dei lation, y que vulgarmente se conservan, vayan a pasear y no se inetan a bablar de lo que no entienden. Lá sintaxis de la lengua latina es una colıvie de reglas que jamás hubo, puts esas que llaman reglas, no son sino unos descuidos o ignorancias de los que escribieron latín antes o después de Gicerón. Dejo aparte el que la len- 
gua latina no tiene voces para significar las cosas de la Historia Natural y para significar las cosas artificiales que no había en lo antiguo. Siempre serán voces bárbaras o de puro capricho.

775. Aquí se palpará el mucho tiempo que se ahorrará y la más claca inteligencia que se añadirá en el estudio de la lengua latina si, antes, se estudia la lengua y gramática de una lengua vulgar que sea dialecto de la latina. Y si se. dedica al estudio de las etimologías de las voces vulgares, que es el principal fundamento para penetrar mejor toda ciencia humana, se descubrirán muchas voces de pura latimidad que se han perdido. Bien sé que muchos se ríen del estudio de las etmologías, porque lo tienen por falso, fallido y falaz y totalmente voluntario. Varron, San Isidoro, Vossio, Salmasio, Escalígero, Bochart, Menage, Leibnitz, etc., no hubieran sido tan eruditos si no poseyesen el estudio de las etimologías. El Etymologicum Magnum de los griegos, el Etymologicon de Matías Martini, el Etimológico inglés de Skyner, el Teotisco de Schilter, el Etymológico de Plantavitio para voces castellanas deducidas del hebreo, etc., todos se deben tener presentes para aumentar y rectificar el Tesoro de la lengua castellana de Cavarrubias.

* 76. No pretendo que el lector se arrime al dictamen que he apuntado en estos cinco pliegos que escribí deprisa, de paso, y tumultuariamente; y en los cuales he soltado algunas especies nada vulgares, por si alguna puede servir para corregir el método de estudios que se ha presentado. No dudo que habrá tantos métodos distintos, cuantos fuesen los estudiantes. Y de mi voto, cualquier estudiante que estuviere ya medianamente instruido, ese solo será el que ha de inventar el método de sus estudios, sin hacer caso de métodos ajenos.

77. Después que nazcá y se bautice el niño, todo cuidado de los padres ha de ser para que comiemes a hablar. Después, se le ha de enseñar la doctrina cristiana y las oraciones de la Iglesia, rezando todos los días el rosario. A la madre toca instruirle on las buenas costumbres de cortesía y política. El padre ha de dirigirle en la loquela y clara pronunciación de la lengua nativa. He conocido a muchos, cargados de barbas, y a filósofos, médicos, teólogos y juristas de escuela, que no sabían el latín de muchas voces vulgares castellanas, ni las correspondientes voces castellanas de sus latines chapuceros.

»78. Es desatino creer que por Vocabularios se aprenden las lenguas. Las voces colocadas por el $\mathrm{ABC}$ han tenido la culpa de aquella ignorancia. Desterraría de los estudios aquellos Vocabularios alfabetos y los substituiría por Onomásticos. Llámase onomástico o nomenclator aquel tomo en que están colocados los nombres de las cosas por clases, como el Onomástico Grecolatino de Julio Pollux, escrito por los años doscientos de Cristo. Las voces por el ABC 
no dan un harapo de substancia, fuera de la explicación de la pura voz. Puestas las cosas por clases, de un solo golpe se saben muchas cosas y la conexión de ellas. Un onomástico universal de cosas en castellano, y divididas por clases de cosas de la Iistoria Natural, de cosas artificiales, y de cosas divinas, será una divina obra para la pronta educación de la juventud española. Con solo Jeerla, el niño se hará cargo de todas las cosas del mundo.

"79. El Arbol Predicamental en que están colocadas las cosas, ens, substantia, compts, binens, animal, homo, petnes, se conserva de inmeniorial en las escuelas. Y a no ser por ese Ábot, no se sabría formar un silogismo formal. El sistema sepherutico, o de las voces sephiras, que rae el P. Kircher, pág. 288 de su Oedipo Aegipciaco, tomo II, es a imitación del Arbol Predicanental, en et cual los antiguos hebreos hacen sus combinaciones cabalísticas toleradas. Entre esas, pone Kircher, pág. 319, las diez puertas de la inteligencia. Esto es, colocan los hebreos antiquísimos, como en monomástico de cosas, cinco clases y en cada clase diez pucrtas. La primera clase es de los elementos, la segunda de los mixtos, la tercora del hombre, la cuarta de las esferas celestes y la quinta de los ángeles. Y la puerta cincuenta, y en la clase quinta, trata de Dios immenso. Solo Cristo penetró esta pucrta cincuenta. Moisés no pasó de la cuarenta y nueve. Josué no pasó de la cuarenta y ocho y lo mismo digo de Salomón. Esta serie o cadena de cosas, alude a la cadena de oro que hajaha de Júpiter hasta la Tierra, y de la cual, tirando todos los dioses, jamás pudieron remover a Jípiter del ciclo.

\$80. Yo imagino que desde la esencia divina hasta la última piltrafa de la materia, las cuarenta y nueve puertas, todas, son de las cosas que Dios ha criado. Y los querubines son los que más cerca están del Criador. Si en esa serie o cadena de cosas críadas supićramos qué orden o lugar acupa esta o la otra cosa, no había más que desear. Yo confieso que no lo sé, ni he sido autor que haya pensado en ello; y es porque todo el estudio es de voces, y no de cosas. Dicen de los chinos que tienen ochenta mil caracteres, porque un carácter solo significa una cosa; y así, el mís docto chino sabe y conoce ochenta mil cosas. Si esos chinos pensasen en hacer un onomástico de su lengua, podría ser que, colocadas las cosas en serie, se hallase alguna conexión entre los caracteres respectivos. Es evidente que si, en lugar de caracteres, se pintasen a lo vivo las cosas, coordinadas estas en serie, enseñarian más que con los caracteres.

"81. El padre del niño, o el maestro, ha de procurar tener un tomo del Onomástico Castellano, o, si no le hay, que uno de los dos lo forme, pues nada tiene de dificultad, y ha de venir a parar en que el mismo niño haga otro onomástico par sí, cuando sepa escribir medianamente. Entréguesele al niño un 
cuademillo en cuarto, escríbase en las cabezas la clase. Después, salga el niño a pasear, y todas cuantas voces castellanas oyere a su padre, su madre, sus parientes, o su maestro, y a los niños de la calle, escríbalas con su significado en el cuaderno. El latín y griego correspondiente se pondrán más adelante.

»82. Tengo presente, y sobre la mesa, un tomillo de Onomástico en italiano y latín, traducido del francés. Su autor el P. Pomey. El onomastiquillo tiene doscientas cuarenta y tres clases y capítulos. Teniendo presente este Onomástico italiano-Latino, o el Onomasticon graeco-latino de Julio Pollux, se podrá formar el Onomástico castellano-latino, que sirva para la educación de la juventud. No se repare en si se gasta mucho o poco papel. El juego del Theatrum Vitae Humanae, del Beyer-Lincke no es otra cosa que el Theatrum Humanae Vitae de Theodoro, y su hijo Jacobo Zuinguero, en nueve columnas; con esta diferencia: que Beyer-Lincke solo colocó las voces del Theatro de Zuinguero por el alfabeto, siendo así que los Zuingueros trataron de las cosas por materias y por clases.

»83. Sirviendo de modelo el Onomástico italiano del P. Pomey, se ha de comenzar el Onomástico castellano-latino, mas que suba a dos o tres tomos en folio. Pero el borrador que se ha de escribir en cuarto, comenzará desde Dios y cosas divinas; bajará por los ángeles y cosas espirituales; después por las esferas y cosas celestes; después, del hombre y de la naturaleza humana; después, de la clase de los mixtos de la Historia Natural en sus tres reinos, mineral, vegetativo y sensitivo; $y$, al fin, de los elementos y de sus combinaciones, hasta la más mínima y desaparecida parte de la materia, que es la materia prima. En estas clases, están resumidas las cincuenta Puertas de la Inteligencia de los antiguos hebreos.

»84. Estos, con su sistema Sephiroth de las esferas, con las treinta y dos sendas y con el nombre de Dios Jeovah, o Tetragrammaton, hacen sus comistrajos; y como que penetran todas las cosas del mundo. Hecho ya el Onomástico, jamás el niño le ha de dejar de las manos, ni aunque tenga ochenta y un años de edad. A lo último de ese Onomástico de las cosas, ha de haber un índice universal de todas las voces, con reclamo al lugar en donde están colocadas y explicadas. Ese índice de voces ha de seguir el orden del ABC.

»85. ¿Quiero enterarme de la cosa significada por esta voz: león? Búscola en el índice universal; y en el lugar citado, hallo explicada la naturaleza del león, sus sinónimos, la voz latina y griega correspondiente, la etimología de la voz, las proporciones del león y sus virtudes medicinales, etc. A ese modo, se podrá hacer cargo el niño de todas las demás cosas de este mundo, y, al mismo tiempo, de sus nombres. Todas las artes y ciencias se reducen a cosas y voces, 
y cuando se para en las voces, nunca se adquiere ciencia ni arte alguna. Es indispensable, para eso, comprender y penetrar las cosas significadas por las voces vulgares castellanas. ¿Y qué diremos de los que se desdeñan de hablar, entender y penetrar la lengua que han mamado? Que no pasarán de mamacallos, por más que frecuenten las escuelas.

^86. Insisto en que, antes de la lengua y la gramática latina, sc cstudic la lengua y la gramática vulgar. Y en ocho días se sabrá lo que tantos años cuesta, y cuesta tantos castigos, y, al fin, no se aprende. Esos castigos, aplíquense a los que, sin saber, se han metido a enseñar por el vil interés del minerval. La lengua latina era vulgar al tiempo de Cicerón; y era vulgar la griega en tiempo de Aristóteles; y en esas dos lenguas se enseñaron las ciencias metafísicas. ¿Cuánto ha de durar, pues, el delirio de estudiarlas por una lengua muerta? Uno que haya estudiado las matemáticas por el P. Tosca, en vulgar, después las estudiará mejor por el P. Millet en latín.

"87. Digo, pues, que si en España hay hoy decadencia en la literatura, también la había el año pasado o en el pasado siglo, pues había el mismo método de csudiar. Y me temo que si ese se inuda sin conocimiento de causa, cadá día crecerá mús esá decadencia. Y Dios quiera que mi ternor salga huero y vano. Mes de abril de 1769. 